\title{
THE EFFECTS OF FAMILY AND WORKPLACE ON THE BURNOUT LEVELS OF RADIOGRAPHERS WORKING IN ONCOLOGY PATIENT CARE
}

\author{
Dávid SIPOS ${ }^{1,2,3}$, Csaba VANDULEK ${ }^{2}$, Attila András PANDUR ${ }^{1}$, Péter KOVÁCS ${ }^{2,3}$, \\ Szabolcs CSEH ${ }^{1}$, András KEDVES ${ }^{1,2,3}$, József TOLLÁR R ${ }^{2,3}$, Árpád KOVÁCS ${ }^{1,2,4}$, \\ Imre REPA ${ }^{1,3}$, Melinda PETÖNÉ CSIMA ${ }^{1,5}$ \\ 1 Doctoral School of Health Sciences, University of Pécs, Pécs, Hungary \\ 2 Department of Medical Imaging, Faculty of Health Sciences, University of Pécs, Pécs, Hungary \\ 3 Dr. József Baka Diagnostic, Radiation Oncology, Research and Teaching Center, "Moritz Kaposi”Teaching Hospital, Kaposvár, \\ Hungary \\ 4 Department of Oncoradiology, Faculty of Medicine, University of Debrecen, Hungary \\ 5 Faculty of Pedagogy, Szent István University Kaposvár Campus, Kaposvár, Hungary \\ Corresponding author: Sipos Dávid; e-mail: cpt.david.sipos@gmail.com
}

Received: 12.11 .2020

Accepted: 29.12 .2020

https://doi.org/10.47724/MIRTJ.2020.i02.a001

\begin{abstract}
Purpose: The aim of the study was to explore the burnout rate of radiographers working in oncology patient care.

Materials and methods: Cross-sectional and targeted nonrandom sampling research was conducted from June 2018 to September 2018. We used the Maslach Burnout Inventory supplemented with our own questionnaire for online data collection. In addition to demographic aspects, we collected data on job characteristics to examine the predictors of burnout. Statistical analysis was performed using descriptive statistics. A two-sampled t-test, analysis of variance, the MannWhitney test and the Kruskal-Wallis test were used at a 95\% confidence level $(p=0.05)$.
\end{abstract}

Results: We analyzed data of 72 radiographers working in oncology patient care $(n=72)$ and 332 radiographers working in other areas of patient care $(n=332)$. The value of emotional exhaustion $(p=0.001)$ was significantly higher in radiographers working in oncology patient care. Respondents who were single, provided monthly on-call duty and held university degrees showed signs of depersonalization $(p=0.001)$. Having a second job, working over 40 hours per week and participating in on-call duty services had a negative effect on emotional exhaustion $(p=0.001)$. The value of personal accomplishment $(p=0.001)$ was significantly better in respondents with more than one child in their household. The subjective assessesment of poor financial status had a negative effect on all three dimensions of burnout $(p=0.001)$.

Conclusion: The mean values of emotional exhaustion in radiographers working in oncology patient care increased significantly. The observed higher value of personal accomplishment demonstrates the positive feedback given by patients to radiographers.

Keywords: radiographer, burnout, oncology, Maslach Burnout Inventory 


\section{INTRODUCTION}

Healthcare professionals are at an increased risk of burnout due to the nature of their work. In their roles, they consistently provide help and care to patients, which requires both emotional stamina and empathy. In order to perform their tasks smoothly, it is essential that they are able to make quick and definite decisions, whilst being professional in any situation. The nature of healthcare work presupposes effective collaboration amongst the healthcare staff, an appropriate level of communication and an empathetic approach towards patients (1).

\section{Burnout}

Burnout is defined in the following three dimensions: depersonalization, emotional exhaustion, and an identified sense of decreased personal accomplishment. Previous research in the service sector was based on the internationally validated Maslach Burnout Inventory (MBI), a questionnaire designed to measure the three above mentioned scales (2). Depersonalization refers to an individual frequently feeling as if they are outside observers of their own lives. Individuals with a depersonalization disorder perceive their self-identity, body, and life in a distorted form that fills them with discomfort (3). Emotional exhaustion is the feeling when an employee is no longer able to provide more on a psychological level. An individual feels that they have reached the physical and emotional limit of their abilities. A sense of decreased personal efficiency results in individuals' negative evaluation of their performance. They might also view themselves as underperforming in comparison with their peers (3).

The emotional burden associated with the care of cancer patients and those with terminal conditions has been previously recognized among those working in oncology patient care. Based on the results of Dougherty et al., healthcare professionals working in acute and oncology patient care demonstrate higher workplace stress and lower job satisfaction rates than those working in other areas of healthcare. This suggests that workplace stress is influenced by the organization and culture of the work environment, and the nature of work. The results of the survey confirmed that high stress levels in acute oncology conditions are associated with a high workload and low control over the work environment $(4,5,6,7)$.

Work-related stress can cause problems in patient care, either because the quality of the provided care deteriorates or because the overburdened healthcare workers' absences from work have a detrimental effect on the rest of the healthcare professionals as they experience an increased workload (8).

The incidence of cancer patients places an increased burden on patient care units (9). Due to complex oncology treatments and close monitoring of patients' health status, healthcare professionals working in oncology patient care are at a particular risk of work-related stress and burnout $(10,11)$.

Recent reviews of burnout suggest that the theoretical foundations of research in the field of oncology need to be strengthened, and that future work should focus more on organizational factors for burnout prevention (12). Burnout can have serious consequences such as substandard performance of health care, effects on the work environment including reduced working hours, taking work breaks more frequently, or a reduced affinity toward employee morale $(2,3)$.

In our research published in 2019, we examined the burnout level of staff working in the radiology department in terms of education, years of service in healthcare and age groups (13). The purpose of our current study was to assess the extent of burnout among radiographers working in oncology care units and to highlight the possible causes of phenomenon that may be related to family and work characteristics in contrast to radiographers working in other fields of patient care.

\section{MATERIALS AND METHODS}

Approval for this study was obtained from the Society of Hungarian Radiographers, Budapest, Hungary. Regarding our quantitative, cross-sectional research, we initiated a targeted non-random sampling procedure by sending our questionnaire electronically to nearly 3,000 radiographers registered with the Society of Hungarian Radiographers.

In addition to the internationally validated Maslach Burnout Inventory (MBI), we designed a questionnaire related to sociodemographic and workplace characteristics. With regard to the interpretation of the results of the $\mathrm{MBI}$ questionnaire, scores for statements about personal accomplishment were low, while high scores for statements about emotional exhaustion and depersonalization suggest different degrees of burnout $(14,15)$.

\section{Statistical analysis}

We used descriptive statistics, a two-sample t-test, analysis of variance (ANOVA), Kruskal-Wallis, and Mann-Whitney test at a $95 \%$ confidence level $(p=0.05)$. Data processing was implemented with the Statistical Package for the Social Sciences (SPSS) version 24.0 software.

\section{RESULTS}

The questionnaire was completed by a total of 404 respondents $(n=404)$. Based on the aim of our study, our sample was divided into a cohort of radiographers working in oncology patient care $(n=72)$ and radiographers working in other areas of patient care $(n=332)$.

Based on the evaluation of the results of the MBI, it can be observed that the average scores in the dimensions of depersonalization and emotional exhaustion are well above the $\mathrm{MBI}$ normal values, which can be negatively interpreted for both groups in our sample. The value of the personal accomplishment dimension also exceeds the normal values of $\mathrm{MBI}$ however, which means that radiographers working in oncology patient care and other areas of patient care feel more successful and positive in their efforts. There was a significantly increased value of emotional exhaustion among radiographers working in oncology patient care compared to their peers who were measured in the same dimension $(p=0.001)$ (Table 1). 
Table 1: Relationship between mean MBI values of radiographers working in oncology patient care and other fields of patient care compared to normal MBI values (normal values represent the mean values of physicians and nurses)

\begin{tabular}{|l|c|c|c|c|c|}
\hline & & & $\begin{array}{c}\text { Depersonalization } \\
\text { (Mean } \pm \text { SD) }\end{array}$ & $\begin{array}{c}\text { Emotional exhaustion } \\
\text { (Mean } \pm \text { SD) }\end{array}$ & $\begin{array}{c}\text { Personal accomplishment } \\
\text { (Mean } \pm \text { SD) }\end{array}$ \\
\hline $\begin{array}{l}\text { Radiographers working in } \\
\text { oncology patient care }\end{array}$ & & 72 & $13.62 \pm(7.74)$ & $40.28 \pm(11.94)^{* * *}$ & $43.00 \pm(7.02)$ \\
\hline $\begin{array}{l}\text { Radiographers working in } \\
\text { other fields of patient care }\end{array}$ & & 332 & $12.64 \pm(6.35)$ & $32.98 \pm(12.85)^{* * *}$ & $40.60 \pm(8.98)$ \\
\hline$M B$ values & USA & 11.067 & $8.7 \pm(5.9)$ & $22.0 \pm(10.8)$ & $34.6 \pm(7.1)$ \\
\hline
\end{tabular}

*** $p<0.001$

\section{Relationship between family composition and burnout}

The majority $(93.1 \%)$ of the radiographers working in the field of oncology were female $(n=67)$. Among them, the depersonalization subscale value was lower than that of the male radiographers; nevertheless, the female radiographers were more affected in the dimension of emotional exhaustion. The male radiographers' personal achievement subscale value proved to be significantly lower compared to the mean value of the female radiographers $(p=0.01)$. The marital status of the sample reveals that $40.3 \%(n=29)$ live with a spouse/ partner; however, the average value of the depersonalization dimension of those respondents who are single $(n=16 ; 22.2 \%)$ was significantly lower than in other categories of marital status $(p=0.01)$. Marital status had no significant effect on either emotional exhaustion nor personal accomplishment. The results show that $61.1 \%(n=44)$ of the respondents have no children. Respondents with one or more children in their family had significantly lower mean emotional exhaustion $(p=0.05)$ and also a significantly higher personal accomplishment value $(p=0.01)$.

The results show that female respondents were also overrepresented by $84.3 \%(n=280)$ among the radiographers working in other fields of patient care. There was no significant gender difference in respect to the three dimensions of burnout. The mean values also showed similar distribution in every dimension. Regarding the family composition, a significantly lower sense of personal accomplishment was observed in those who lived with other family members/ individuals ( $n=29 ; 8.7 \%$ ) compared to those with a different type of family composition $(p=0.01)$. Regarding the number of children in the family, significantly higher burnout was observed in the dimensions of depersonalization $(p=0.01)$ and emotional exhaustion $(p=0.05)$ for respondents who did not have children in their family; values of personal achievement $(p=0.05)$ were also significantly lower.

\section{Subjective financial situation assessment and the relationship between education and burnout}

The results for the radiographers working in oncology patient care show that $63.9 \%(n=43)$ of the sample consider that they live well from their salary and are able to make regular savings from their income. Those respondents $(8.3 \%, n=6)$ whose salary was not sufficient to make a living, (based on their own subjective judgment), had a significantly higher mean of depersonalization and emotional exhaustion. Furthermore, their mean value measured on the personal accomplishment subscale was significantly lower compared to other respondents $(p=0.001 ; p=0.001 ; p=0.05)$.

Radiographers with a Bachelor's degree predominated in the sample at $69.4 \%(n=50)$. Those respondents who hold a Master's degree $(n=14 ; 19.4 \%)$ had a significantly higher mean value of depersonalization compared to respondents with tertiary vocational education $(n=8 ; 11.1 \%)(p=0.001)$. Respondents with a completed high school education had a significantly lower level of emotional exhaustion compared to those with a completed higher education $(p=0.01)$.

Based on their subjective judgment, respondents who did not have enough monthly income to make a living and did not work in oncology patient care, had a significantly increased emotional exhaustion value $(\mathrm{p}=0.01)$ and had a significantly lower value of personal accomplisment $(p=0.01)$.

In terms of educational level, more than half of the respondents in the sample had a university degree $(n=188$; $56.6 \%)$. This group showed a significantly elevated value in the depersonalization subscale compared to respondents with completed tertiary vocational education $(n=109 ; 32.8 \%)$ and secondary education $(n=35 ; 10.5 \%)(p=0.05)$ (Table 2$)$.

\section{The effects of workplace characteristics on burnout}

The results show that $13.9 \%$ of the respondents $(n=10)$ had a second job. The average emotional exhaustion value of this group was significantly higher than the average value of those without a second job $(\mathrm{p}=0.001)$. Respondents who worked more than 40 hours per week ( $n=64 ; 88.9 \%$ ) were significantly more prevalent in the dimensions of depersonalization and emotional exhaustion $(p=0.001 ; p=0.001)$. The majority of the respondents in the sample $(n=65 ; 90.3 \%)$ did not participate in on-call shifts; nevertheless, those radiographers $(n=7$; 9.7\%) who provided on-call shifts (1-3 times per month) had depersonalization and emotional mean values which significantly deviated in the negative direction $(p=0.001$; $p=0.001$ ). We also measured a significant difference between the above two groups in the average value of the dimension of personal achievement, with the result showing that the oncall staff have a positive experience in relation to the way they judge the success of their efforts at work.

The assessment examined how the radiographers view their relationship with their colleagues. Based on the results of the study, the majority $(n=52 ; 72.2 \%)$ of the sample experienced a good relationship with their colleagues. The mean value 
Table 2: Respondents' values measured by the MBI burnout questionnaire on the subscales of depersonalization, emotional exhaustion, and personal accomplishment in relation to gender, family status, number of children in the family, financial situation and level of education.

\begin{tabular}{|c|c|c|c|c|c|c|c|c|}
\hline \multirow[b]{2}{*}{ Value } & \multirow[b]{2}{*}{$n(\%)$} & \multicolumn{3}{|c|}{$\begin{array}{c}\text { Radiographers working in } \\
\text { oncology patient care }\end{array}$} & \multirow[b]{2}{*}{$n(\%)$} & \multicolumn{3}{|c|}{$\begin{array}{c}\text { Radiographers working in other fields } \\
\text { of patient care }\end{array}$} \\
\hline & & $\begin{array}{l}\text { Depersonali- } \\
\text { zation }\end{array}$ & $\begin{array}{l}\text { Emotional } \\
\text { exhaustion }\end{array}$ & $\begin{array}{l}\text { Personal } \\
\text { accomplish- } \\
\text { ment }\end{array}$ & & $\begin{array}{l}\text { Depersonali- } \\
\text { zation }\end{array}$ & $\begin{array}{l}\text { Emotional } \\
\text { exhaustion }\end{array}$ & $\begin{array}{c}\text { Personal } \\
\text { accomplish- } \\
\text { ment }\end{array}$ \\
\hline \multicolumn{9}{|c|}{ Gender } \\
\hline Men & $\begin{array}{c}5 \\
(6.9)\end{array}$ & $\begin{array}{c}16.60 \\
(S D=6.98)\end{array}$ & $\begin{array}{c}36.80 \\
(\mathrm{SD}=16,34)\end{array}$ & $\begin{array}{c}34.60 \\
(\mathrm{SD}=12.03)^{* *}\end{array}$ & $\begin{array}{c}52 \\
(15.7)\end{array}$ & $\begin{array}{c}15.63 \\
(\mathrm{SD}=4.67)\end{array}$ & $\begin{array}{c}32.08 \\
(\mathrm{SD}=9.72)\end{array}$ & $\begin{array}{c}38.29 \\
(\mathrm{SD}=9.46)\end{array}$ \\
\hline Women & $\begin{array}{c}67 \\
(93.1)\end{array}$ & $\begin{array}{c}13.40 \\
(\mathrm{SD}=7.80)\end{array}$ & $\begin{array}{c}40.54 \\
(S D=11.67)\end{array}$ & $\begin{array}{c}43.63 \\
(S D=6.20)\end{array}$ & $\begin{array}{c}280 \\
(84.3)\end{array}$ & $\begin{array}{c}12.08 \\
(\mathrm{SD}=6.46)\end{array}$ & $\begin{array}{c}33.14 \\
(S D=13.35)\end{array}$ & $\begin{array}{c}41.04 \\
(\mathrm{SD}=8.83)\end{array}$ \\
\hline \multicolumn{9}{|c|}{ Family status } \\
\hline $\begin{array}{l}\text { Living with spouse/ } \\
\text { partner }\end{array}$ & $\begin{array}{c}29 \\
(40.3)\end{array}$ & $\begin{array}{c}13.66 \\
(\mathrm{SD}=7.70)\end{array}$ & $\begin{array}{c}41.66 \\
(\mathrm{SD}=11.21)\end{array}$ & $\begin{array}{c}44.45 \\
(\mathrm{SD}=5.83)\end{array}$ & $\begin{array}{c}127 \\
(38.3)\end{array}$ & $\begin{array}{c}11.96 \\
(\mathrm{SD}=4.76)\end{array}$ & $\begin{array}{c}31.73 \\
(\mathrm{SD}=12.97) \\
\end{array}$ & $\begin{array}{c}40.79 \\
(\mathrm{SD}=8.59)\end{array}$ \\
\hline $\begin{array}{l}\text { Living with spouse/ } \\
\text { partner and with } \\
\text { children }\end{array}$ & $\begin{array}{c}18 \\
(25.0)\end{array}$ & $\begin{array}{c}15.97 \\
(\mathrm{SD}=7.43)\end{array}$ & $\begin{array}{l}38.17 \\
(\mathrm{SD}=11.70)\end{array}$ & $\begin{array}{c}40.28 \\
(S D=10.19)\end{array}$ & $\begin{array}{c}82 \\
(24.7)\end{array}$ & $\begin{array}{c}12,05 \\
(\mathrm{SD}=6.64)\end{array}$ & $\begin{array}{c}34.70 \\
(\mathrm{SD}=11.32)\end{array}$ & $\begin{array}{c}42.16 \\
(\mathrm{SD}=7.83)^{* *}\end{array}$ \\
\hline Single & $\begin{array}{c}16 \\
(22.2)\end{array}$ & $\begin{array}{c}9.88 \\
(S D=7.58)^{* *}\end{array}$ & $\begin{array}{c}40.81 \\
(\mathrm{SD}=13.41)\end{array}$ & $\begin{array}{c}43.31 \\
(\mathrm{SD}=4.34)\end{array}$ & $\begin{array}{c}94 \\
(28.3)\end{array}$ & $\begin{array}{c}13.89 \\
(\mathrm{SD}=7.36)^{*}\end{array}$ & $\begin{array}{c}32.95 \\
(\mathrm{SD}=13.95)\end{array}$ & $\begin{array}{c}40.45 \\
(\mathrm{SD}=9.22)\end{array}$ \\
\hline $\begin{array}{l}\text { Living with other } \\
\text { person/family } \\
\text { member }\end{array}$ & $\begin{array}{c}9 \\
(12.5)\end{array}$ & $\begin{array}{c}15.56 \\
(S D=7.43)\end{array}$ & $\begin{array}{c}39.11 \\
(\mathrm{SD}=13.42)\end{array}$ & $\begin{array}{c}43.22 \\
(S D=6.11)\end{array}$ & $\begin{array}{c}29 \\
(8.7)\end{array}$ & $\begin{array}{c}13.17 \\
(S D=7.0)\end{array}$ & $\begin{array}{c}33.66 \\
(S D=12.75)\end{array}$ & $\begin{array}{c}35.90 \\
(S D=11.41)^{* *}\end{array}$ \\
\hline \multicolumn{9}{|c|}{ Number of children } \\
\hline One & $\begin{array}{c}16 \\
(22.2)\end{array}$ & $\begin{array}{c}13.44 \\
(\mathrm{SD}=8.31)\end{array}$ & $\begin{array}{c}42.31 \\
(S D=12.13) \\
\end{array}$ & $\begin{array}{c}39.81 \\
(\mathrm{SD}=10.39)\end{array}$ & $\begin{array}{c}82 \\
(24.7)\end{array}$ & $\begin{array}{c}11.91 \\
(S D=6.70)\end{array}$ & $\begin{array}{c}31.13 \\
(\mathrm{SD}=12,84) \\
\end{array}$ & $\begin{array}{c}42-65 \\
(S D=8.5)^{*}\end{array}$ \\
\hline More than one & $\begin{array}{c}12 \\
(16.7)\end{array}$ & $\begin{array}{c}11.92 \\
(S D=7.15)\end{array}$ & $\begin{array}{c}33.08 \\
(S D=11.22)^{*}\end{array}$ & $\begin{array}{c}47.50 \\
(S D=4.70)^{* *}\end{array}$ & $\begin{array}{c}107 \\
(32.2)\end{array}$ & $\begin{array}{c}11.22 \\
(\mathrm{SD}=6.32)\end{array}$ & $\begin{array}{c}32.53 \\
(\mathrm{SD}=13.20) \\
\end{array}$ & $\begin{array}{c}40.69 \\
(S D=10.09\end{array}$ \\
\hline None & $\begin{array}{c}44 \\
(61.1)\end{array}$ & $\begin{array}{c}14.16 \\
(S D=7.80)\end{array}$ & $\begin{array}{c}41.50 \\
(\mathrm{SD}=11.59)\end{array}$ & $\begin{array}{c}42.93 \\
(\mathrm{SD}=5.35)\end{array}$ & $\begin{array}{c}143 \\
(43.1)\end{array}$ & $\begin{array}{c}14.10 \\
(S D=5.87)^{* *}\end{array}$ & $\begin{array}{c}34.36 \\
(\mathrm{SD}=12.53)^{*}\end{array}$ & $\begin{array}{c}39.36 \\
(S D=8.26)^{*}\end{array}$ \\
\hline \multicolumn{9}{|c|}{ Current financial state } \\
\hline Living well & $4(5.6)$ & $\begin{array}{c}12.50 \\
(\mathrm{SD}=5.10)\end{array}$ & $\begin{array}{c}39.25 \\
(\mathrm{SD}=15.50)\end{array}$ & $\begin{array}{c}43.50 \\
(S D=7.00)\end{array}$ & $\begin{array}{c}13 \\
(3.9)\end{array}$ & $\begin{array}{c}15.54 \\
(S D=717)\end{array}$ & $\begin{array}{c}29.15 \\
(S D=16.24)\end{array}$ & $\begin{array}{c}43.62 \\
(S D=13.25)\end{array}$ \\
\hline $\begin{array}{l}\text { Living good, is able } \\
\text { to save }\end{array}$ & $\begin{array}{c}46 \\
(63.9)\end{array}$ & $\begin{array}{c}11.70 \\
(\mathrm{SD}=7.65)\end{array}$ & $\begin{array}{c}38.11 \\
(\mathrm{SD}=11.23)\end{array}$ & $\begin{array}{c}44.20 \\
(\mathrm{SD}=6.30)\end{array}$ & $\begin{array}{c}182 \\
(54.8)\end{array}$ & $\begin{array}{c}11.99 \\
(\mathrm{SD}=5.65)\end{array}$ & $\begin{array}{c}31.36 \\
(\mathrm{SD}=12.08) \\
\end{array}$ & $\begin{array}{c}40.26 \\
(S D=9.15)\end{array}$ \\
\hline $\begin{array}{l}\text { Just enough to } \\
\text { make a living }\end{array}$ & $\begin{array}{c}16 \\
(22.2) \\
\end{array}$ & $\begin{array}{c}14.94 \\
(\mathrm{SD}=7.57)\end{array}$ & $\begin{array}{c}38.13 \\
(\mathrm{SD}=10.21)\end{array}$ & $\begin{array}{c}41.31 \\
(\mathrm{SD}=9.31)\end{array}$ & $\begin{array}{c}109 \\
(32.8) \\
\end{array}$ & $\begin{array}{c}13.40 \\
(\mathrm{SD}=7.39)\end{array}$ & $\begin{array}{c}34.31 \\
(\mathrm{SD}=13.77) \\
\end{array}$ & $\begin{array}{c}41.36 \\
(\mathrm{SD}=8.81)\end{array}$ \\
\hline $\begin{array}{l}\text { Not enough for } \\
\text { living }\end{array}$ & $6(8.3)$ & $\begin{array}{c}19.14 \\
(\mathrm{SD}=4.45)^{* * * *}\end{array}$ & $\begin{array}{c}49.10 \\
(S D=5.11)^{* * *}\end{array}$ & $\begin{array}{c}38.00 \\
(\mathrm{SD}=4.15)^{*}\end{array}$ & $\begin{array}{c}28 \\
(8.4)\end{array}$ & $\begin{array}{c}12.64 \\
(\mathrm{SD}=5.67)\end{array}$ & $\begin{array}{c}42.12 \\
(S D=11.16)^{* *}\end{array}$ & $\begin{array}{c}37.72 \\
(S D=6.25)^{* * *}\end{array}$ \\
\hline \multicolumn{9}{|c|}{ Level of education } \\
\hline $\begin{array}{l}\text { Secondary } \\
\text {-education }\end{array}$ & $\begin{array}{c}8 \\
(11.1)\end{array}$ & $\begin{array}{c}11.50 \\
(\mathrm{SD}=8.38)\end{array}$ & $\begin{array}{c}29.63^{* *} \\
(\mathrm{SD}=12.48)\end{array}$ & $\begin{array}{c}45.88 \\
(S D=7.31)\end{array}$ & $\begin{array}{c}35 \\
(10.5)\end{array}$ & $\begin{array}{c}12.63 \\
(\mathrm{SD}=6.96)\end{array}$ & $\begin{array}{c}32.17 \\
(S D=13.04)\end{array}$ & $\begin{array}{c}42.69 \\
(S D=7.04)\end{array}$ \\
\hline $\begin{array}{l}\text { Higher vocational } \\
\text { education }\end{array}$ & $\begin{array}{c}14 \\
(19.4) \\
\end{array}$ & $\begin{array}{c}8.86 \\
(S D=4.78)^{* *}\end{array}$ & $\begin{array}{c}36.86 \\
(\mathrm{SD}=13.49) \\
\end{array}$ & $\begin{array}{c}46.79 \\
(\mathrm{SD}=6.47)\end{array}$ & $\begin{array}{c}109 \\
(32.8) \\
\end{array}$ & $\begin{array}{c}10.94 \\
(\mathrm{SD}=6.06)\end{array}$ & $\begin{array}{c}31.52 \\
(\mathrm{SD}=12.93) \\
\end{array}$ & $\begin{array}{c}41.34 \\
(\mathrm{SD}=9.11)\end{array}$ \\
\hline $\begin{array}{l}\text { University degree } \\
\text { (BSC., Msc.) }\end{array}$ & $\begin{array}{c}50 \\
(69.4)\end{array}$ & $\begin{array}{c}15.30 \\
(\mathrm{SD}=7.79)^{* * *}\end{array}$ & $\begin{array}{c}42.91 \\
(S D=10.35)\end{array}$ & $\begin{array}{c}41.48 \\
(\mathrm{SD}=6.69)\end{array}$ & $\begin{array}{c}188 \\
(56.6)\end{array}$ & $\begin{array}{c}15.54 \\
(\mathrm{SD}=5.79)^{*}\end{array}$ & $\begin{array}{c}30.19 \\
(\mathrm{SD}=11.1)\end{array}$ & $\begin{array}{c}42.66 \\
(\mathrm{SD}=8.67)\end{array}$ \\
\hline
\end{tabular}

${ }^{*} \mathrm{p} \leq 0.05 \quad{ }^{* *} \mathrm{p} \leq 0.01 \quad * * * \mathrm{p} \leq 0.001$

of the emotional exhaustion subscale of those respondents who state that they have poor collegial relationship $(n=16$; $22.2 \%)$ showed a significantly increased value compared to those who assumed as to having good collegial relationship $(p=0.010)$. The values of those who felt that they had excellent collegial relationship ( $n=4 ; 5.6 \%$ ) were significantly higher $(p=0.010 ; p=0.001)$ on the depersonalization and emotional exhaustion subscales.

Those radiographers who work in various other nononcology patient care and have a secondary job $(n=81 ; 24.4)$ showed significantly higher depersonalization and emotional exhaustion values $(p=0.001 ; p=0.001)$. Respondents who worked more than 40 hours per week $(n=225 ; 67.7 \%)$ also showed a significant increase of depersonalization and emotional exhaustion $(p=0.001 ; p=0.001)$. Monthly oncall duty had no significant effect on the dimensions of burnout. Based on the answers to the questions related to the subjectively judged employee relationship, $63.9 \%$ of the respondents $(n=212)$ assumed that they had a good relationship with their colleagues. Depersonalization and 
emotional exhaustion were significantly higher in those radiographers with poor collegial relationships $(n=52 ; 15.7 \%)$ and were significantly lower in the dimensions of personal accomplishment $(p=0.001 ; p=0.001 ; p=0.001)$ (Table 3$)$.

\section{DISCUSSION}

The majority of research in Hungary focusing on the quality of life and burnout of healthcare professionals is related to healthcare professionals working with severely ill patients. According to our knowledge, there has not yet been a survey on burnout conducted among radiographers working in oncology patient care units.

The incidence of prostate and lung cancer has increased dramatically since the middle of the millennium. The constantly evolving technology allows for a maximum effectiveness of oncology treatments relative to the potential of the workplace and the patient's health status $(16,17)$. In addition to the oncologists working in the oncology patient care unit, radiographers play a key role in the implementation of these treatments. Those working in oncology patient care treat patients with specific characteristics compared to other patient care units. During the course of the disease, oncology patients often experience psychological problems, vulnerability, anxiety, fear, and depression, which may be related to an increased stress factor that may be aimed towards treatment providers. In their analysis, Kubota et al. mention that in addition to these factors, nurses working in oncology care also have to deal with ethically complex clinical decisionmaking situations such as the complexity of tumor treatments, grief, communicating bad news and death. These situations do not necessarily occur in other services for chronic patients, such as primary care and emergency care, where the contact time with patients is shorter, or services where patients spend most of the time under the effect of sedatives, such as in the operating room. For these reasons, it can be predicted that the burnout of oncology patient care professionals may show elevated values $(18,19,20)$.

In their study, Révay et al. mention that health care workers dealing with severely ill patients are exposed to greater physical and mental strain than those working in other areas of health care. Their survey that analyzed burnout and coping strategies of hospice workers found that hospice workers were overworked as nearly $50 \%$ of the respondents in the sample worked 12 hours a day, had self-esteem disorders, and more than $70 \%$ of respondents remembered having difficulty sleeping at work. It should be emphasized that, in addition to physical and mental strain, satisfaction arising from compassion is also present in the examined job, which means that employees are also satisfied with their profession, but the negative impact of difficulties in the workplace should not be overlooked (21).

Table 3: Relation of workplace characteristics with the mean values of the dimensions of the Maslach Burnout Inventory

\begin{tabular}{|c|c|c|c|c|c|c|c|c|}
\hline \multirow[b]{2}{*}{ Value } & \multirow[b]{2}{*}{$n(\%)$} & \multicolumn{3}{|c|}{$\begin{array}{l}\text { Radiographers working in } \\
\text { oncology patient care }\end{array}$} & & \multicolumn{3}{|c|}{$\begin{array}{c}\text { Radiographers working in other fields } \\
\text { of patient care }\end{array}$} \\
\hline & & $\begin{array}{c}\text { Depersonali- } \\
\text { zation }\end{array}$ & $\begin{array}{l}\text { Emotional } \\
\text { exhaustion }\end{array}$ & $\begin{array}{c}\text { Personal } \\
\text { accomplish- } \\
\text { ment }\end{array}$ & $n(\%)$ & $\begin{array}{c}\text { Depersonali- } \\
\text { zation }\end{array}$ & $\begin{array}{l}\text { Emotional } \\
\text { exhaustion }\end{array}$ & $\begin{array}{c}\text { Personal } \\
\text { accomplish- } \\
\text { ment }\end{array}$ \\
\hline \multicolumn{9}{|c|}{ Second job } \\
\hline Yes & $\begin{array}{c}10 \\
(13.9)\end{array}$ & $\begin{array}{c}13.40 \\
(\mathrm{SD}=7.23)\end{array}$ & $\begin{array}{l}53.60^{* * *} \\
(\mathrm{SD}=3.09)\end{array}$ & $\begin{array}{c}41.60 \\
(S D=4.64)\end{array}$ & $\begin{array}{c}81 \\
(24.4)\end{array}$ & $\begin{array}{c}15.10 \\
(S D=7.39)^{* * *}\end{array}$ & $\begin{array}{c}39.90 \\
(\mathrm{SD}=12.92)^{* * *}\end{array}$ & $\begin{array}{c}39.15 \\
(\mathrm{SD}=9.13)\end{array}$ \\
\hline No & $\begin{array}{c}62 \\
(86.1)\end{array}$ & $\begin{array}{c}13.66 \\
(\mathrm{SD}=7.88)\end{array}$ & $\begin{array}{c}38.13 \\
(\mathrm{SD}=11.44)\end{array}$ & $\begin{array}{c}43.23 \\
(S D=7.33)\end{array}$ & $\begin{array}{c}251 \\
(75.6)\end{array}$ & $\begin{array}{c}11.84 \\
(S D=5.76)\end{array}$ & $\begin{array}{c}30.74 \\
(\mathrm{SD}=12.03)\end{array}$ & $\begin{array}{c}41.07 \\
(\mathrm{SD}=8.89)\end{array}$ \\
\hline \multicolumn{9}{|c|}{ Number of hours worked per week } \\
\hline $\begin{array}{l}\text { Less than } \\
40 \text { hours }\end{array}$ & $\begin{array}{c}8 \\
(11.1)\end{array}$ & $\begin{array}{c}12.92 \\
(\mathrm{SD}=7.57)\end{array}$ & $\begin{array}{c}39.13 \\
(\mathrm{SD}=12.12)\end{array}$ & $\begin{array}{c}41.25 \\
(\mathrm{SD}=9.54)\end{array}$ & $\begin{array}{c}107 \\
(32.2)\end{array}$ & $\begin{array}{c}11,22 \\
(\mathrm{SD}=5.31)\end{array}$ & $\begin{array}{c}27.16 \\
(\mathrm{SD}=10.84)\end{array}$ & $\begin{array}{c}39.80 \\
(\mathrm{SD}=9.07)\end{array}$ \\
\hline $\begin{array}{l}\text { More than } \\
40 \text { hours }\end{array}$ & $\begin{array}{c}64 \\
(88.9)\end{array}$ & $\begin{array}{c}19.25 \\
(\mathrm{SD}=7.18)^{* *}\end{array}$ & $\begin{array}{c}49.50 \\
(S D=3.92)^{* *}\end{array}$ & $\begin{array}{c}43.22 \\
(\mathrm{SD}=6.70)\end{array}$ & $\begin{array}{c}225 \\
(67.7)\end{array}$ & $\begin{array}{c}15.25 \\
(\mathrm{SD}=6.79)^{* * *}\end{array}$ & $\begin{array}{c}39.06 \\
(\mathrm{SD}=12.59)^{* * *}\end{array}$ & $\begin{array}{c}39.06 \\
(\mathrm{SD}=8.90)\end{array}$ \\
\hline \multicolumn{9}{|c|}{ On-call duties } \\
\hline none & $\begin{array}{c}65 \\
(90.3)\end{array}$ & $\begin{array}{c}12,28 \\
(\mathrm{SD}=6.89)\end{array}$ & $\begin{array}{c}39.05 \\
(\mathrm{SD}=11.92)\end{array}$ & $\begin{array}{c}42.74 \\
(S D=7.34)\end{array}$ & $\begin{array}{c}134 \\
(40.4)\end{array}$ & $\begin{array}{c}12.30 \\
(\mathrm{SD}=6.10)\end{array}$ & $\begin{array}{c}33.29 \\
(\mathrm{SD}=13.23)\end{array}$ & $\begin{array}{c}41.12 \\
(\mathrm{SD}=8.39)\end{array}$ \\
\hline more than one & $\begin{array}{c}7 \\
(9.7)\end{array}$ & $\begin{array}{c}26.14 \\
(S D=3.06)^{* * * *}\end{array}$ & $\begin{array}{c}51.71 \\
(S D=2.13)^{* * *}\end{array}$ & $\begin{array}{c}45.43 \\
(S D=3.53)^{* *}\end{array}$ & $\begin{array}{c}198 \\
(59.6)\end{array}$ & $\begin{array}{c}12.94 \\
(\mathrm{SD}=6.32)\end{array}$ & $\begin{array}{c}33.32 \\
(\mathrm{SD}=12.04)\end{array}$ & $\begin{array}{c}40.35 \\
(S D=8.89)\end{array}$ \\
\hline \multicolumn{9}{|c|}{ Collegial relationship } \\
\hline Excellent & $\begin{array}{c}4 \\
(5.6)\end{array}$ & $\begin{array}{c}15.13 \\
(S D=5.90\end{array}$ & $\begin{array}{c}51.12 \\
(S D=6.18)^{* * *}\end{array}$ & $\begin{array}{c}46.50 \\
(S D=4.45)\end{array}$ & $\begin{array}{c}68 \\
(20.5)\end{array}$ & $\begin{array}{c}10.31 \\
(S D=5.64)\end{array}$ & $\begin{array}{c}25.31 \\
(S D=7.96)\end{array}$ & $\begin{array}{c}43.00 \\
(S D=7.71)\end{array}$ \\
\hline Good & $\begin{array}{c}52 \\
(72.2)\end{array}$ & $\begin{array}{c}12.67 \\
(\mathrm{SD}=7.91)\end{array}$ & $\begin{array}{c}38.08 \\
(\mathrm{SD}=11.68)\end{array}$ & $\begin{array}{c}43.54 \\
(S D=6,16)\end{array}$ & $\begin{array}{c}212 \\
(63.9)\end{array}$ & $\begin{array}{c}12.13 \\
(S D=5.75)\end{array}$ & $\begin{array}{c}32.65 \\
(\mathrm{SD}=12.55)\end{array}$ & $\begin{array}{c}41.54 \\
(S D=8.53)\end{array}$ \\
\hline Bad & $\begin{array}{c}16 \\
(22.2)\end{array}$ & $\begin{array}{c}19.10 \\
\left.(S D=7.14)^{* *}\right)\end{array}$ & $\begin{array}{c}44.25 \\
(S D=11.58)^{* * *}\end{array}$ & $\begin{array}{c}40.38 \\
(\mathrm{SD}=9.61)\end{array}$ & $\begin{array}{c}52 \\
(15.7)\end{array}$ & $\begin{array}{c}21.99 \\
(S D=5.64)^{* * *}\end{array}$ & $\begin{array}{c}50.36 \\
(S D=7.52)^{* * *}\end{array}$ & $\begin{array}{c}33.8 \\
(\mathrm{SD}=5.90)^{* * *}\end{array}$ \\
\hline
\end{tabular}

$* p \leq 0.05 \quad * * p \leq 0.01 \quad * * * p \leq 0.001$ 
The results do not suggest a significant difference in the dimensions of depersonalization and personal accomplishment between radiology professionals working in oncology patient care and other areas of patient care. However, there was a significant difference in the dimension of emotional exhaustion among radiographers working in oncology patient care $(p=0.001)$. This result may be attributed to the increased mental burden associated with the care of terminally ill patients, which is characteristic of oncology patient care $(4,5)$.

Sale et al. examined the burnout rate of those working in oncology care units in Canada. The study analyzed the findings of physicians, nurses, physicists, and radiotherapists. With physicians and radiotherapists, the rate of depersonalization and emotional exhaustion increased in parallel with the time they spent at work (22). In our previously published results, we examined the effect of age and time spent working in healthcare in relation to burnout. We found that radiographers aged between 31-35, as well as those radiographers who have worked in the healthcare system for 16-20 years, were the ones most at risk considering all three dimensions of burnout (22).

Daugherty et al. examined the burnout level of sonographers whose emotional exhaustion was affected by the number of examinations performed weekly. A correlation was found between the type of job and emotional exhaustion, showing that the value of those working in the public sector increased compared to those working in private health care. In addition to workplace factors, male radiographers showed an increased value in the dimension of depersonalization (23).

In light of our own results, male radiographers working in oncology patient care showed increased depersonalization values and decreased emotional exhaustion values compared to female respondents. Regarding the dimension of personal accomplishment, the mean value of men was significantly lower than that of women $(p=0.01)$. The depersonalization value of radiographers working in other areas of patient care also showed an increased value. No significance was detected in the dimensions of emotional exhaustion and personal accomplishment.

A study published by Jaspers et al. found that emotional exhaustion of the non-doctoral workforce in radiotherapy and radiology units is greater than that of physicians, oncologists, and radiologists. The survey also analyzes that those working in the public health sector are more emotionally exhausted than those working in the private sector. The results show that the high workload, the presence of patients and organizational stressors increase emotional exhaustion. Finally, the study found that less work experience and an increased workload significantly affected emotional exhaustion and feelings of depersonalization (24).

When examining our results, we observed a significant increase of emotional exhaustion compared to radiographers working in other areas of patient care. The increased values may be due to the emotional burden characterictic of everyday oncology patient care, a secondary job, participation in monthly on-call duties, the quality of relationships with colleagues, and the perception of a negative financial status.

In his publication, Hegedűs mentions that one of the negative conditions for healthcare workers dealing with critical patients is the lack of the chance to regenerate physically and mentally; therefore he emphasized the importance of implementing methods of burnout prevention. In their survey published at the turn of the millennium, medical training contained only a limited $(0.7 \%)$ number of courses dealing with the issues of death, dying, and mourning. From a mental hygiene point of view, it is of paramount importance that a medical student is able to interpret and process the fate of terminally ill patients with the help of evidence-based literature. According to the author, a time interval of a quarter of an hour a day may be sufficient to settle ones physical and mental condition, which may greatly contribute to the improvement of the quality of the mental load of care for patients $(25,26)$.

The first step in treating the burnout syndrome could be to change the working conditions of the affected staff, with an aim to reduce work overload, yet this is not always possible due to the lack of healthcare staff. However, problems arising at work and in private lives should be resolved and focused group discussions, regular rest periods incorprated in the work schedule, and vacation may be some of the useful methods. Scheiderman et al. discuss the importance of stress-reducing activities and intermittent relaxation in their research to reduce burnout, with some of the most effective activities being group lectures and group discussions in a workplace environment $(27,28,29)$.

According to Szényei et al., primary, secondary and tertiary prevention can play a key role in alleviating and avoiding burnout. These methods include relaxation techniques, cognitive-behavioral therapies, and stress management, the positive effects of which are unquestionable. It is important to emphasize that strategies to reduce burnout need to be interpreted in a rather complex way, and may therefore vary from individual to individual (30).

Kovács et al. studied the emotional exhaustion of those healthcare professionals who work with severely ill patients. They realized that a significant relationship of trust is generated with patients in their daily work and that this relationship grows with personal communication, which can be a positive significant factor regarding burnout. Based on their results, emotional dissonance appears as a significant stress factor among those working in oncology patient care, which may be contributed to the healthcare workers' need to regularly show understanding and express compassion towards patients during their work (31).

Czeglédi and Tandari-Kovács examined the burnout of nurses and concluded that the reason for the shortage of nurses in Hungary is career abandonment and migration. The low degree of social esteem and the increase in both physical and emotional strain also play a role in this phenomenon. Professional psychological help could help professionals, as well as continuous professional development and participation in research activities (32).

Our results show that the burnout syndrome of healthcare professionals working in oncology patient care requires serious attention, mainly due to increased values of depersonalization and emotional exhaustion subscales. It should also be emphasized that various workplace and personal factors such as pay, childlessness, education, having a second job and working more than 40 hours per week, may increase the risk of burnout. To confirm our results, further research is necessary to assess the radiographers working in oncology patient care. Our results suggest that 
increased attention should be paid to the burnout syndrome among professions related to oncology. Our findings of the risk factors may also help establish burnout preventions for healthcare professionals working in high-risk oncology care. Limitations of the study include the impossibility of making a substantive statement about causal relationships due to the retrospective nature of our survey. Also, to the best of our knowledge, a study focusing on burnout has not been conducted among radiographers working in oncology patient care in Hungary. Based on these facts and in light of our results, we propose that decision-makers and management support the development of psychological interventions that contribute to the prevention of burnout of those working in oncology patient care.

\section{CONCLUSION}

In our study of radiographers working in oncology patient care, we examined the significant increase of burnout subscales. Sociodemographic and occupational variables, workplace overcrowding, and workplace-related factors were observed as having a significant influence on the development of the burnout syndrome.

\section{REFERENCES}

1. Fekete S. Segítő foglalkozások kockázatai - Helfer szindróma és burnout jelenség. Psychiatria Hungarica. 1991;4(1):17-27.

2. Maslach C, Jackson S, Leiter M. Maslach Burnout Inventory Manual. 3rd edn. Mountain View,CA:CPP; 2000.

3. Maslach C, Leiter MP. The truth about burnout. San Francisco, CA: Jossey-Bass; 1997.

4. Dougherty M, Pierce B, Clement M, Panzarella T, Rodin G, Zimmermann C. Factors associated with work stress and professional satisfaction in oncology staff. Am J Hosp Palliat Care. 2009;26(2):105-111.

5. Mukherjee S, Beresford B, Glaser A, Sloper P. Burnout, psychiatric morbidity, and work-related sources of stress in paediatric oncology staff: a review of the literature. Psychooncology 2009;18(10):1019-1028.

6. Graham J, Ramirez A, Cull A, Finlay I, Hoy A, Richards M A. Job stress and satisfaction among palliative physicians. Palliat Med 1996;10(3):185-194.

7. Pierce B, Dougherty E, Panzarella T, Le W L, Rodin G, Zimmermann C. Staff stress, work satisfaction, and death attitudes on an oncology palliative care unit, and on a medical and radiation oncology inpatient unit. J Palliat Care 2007;23(1):32-39.

8. Michie S, West M. Measuring Staff Management and Human Resources Performance in the NHS: 2003 NHS Staff Survey. London: Healthcare Commission, 2004.
9. Veres G, Dankó Zs, Balkay L, Bágyi P. Quality control program of diagnostic displays, Magy. Radiol. Online. 2019;10(2):1-10.

10. Sehlen S, Vordermark D, Schafer C, Herschbach P, Bayerl A, Pigorch $S$, et al. Job stress and job satisfaction of physicians, radiographers, nurses and physicists working in radiotherapy: a multicenter analysis by the DEGRO Quality of Life Work Group. Radiat Oncol. 2009;4:6.

11. Ksiasek I, Stefaniak T, Stadnyk M, Ksiazek J. Burnout syndrome in surgical oncology and general surgery nurses: a cross-sectional study. Eur J Oncol Nurs 2011;15(4):347-350.

12. Sherman A, Edwards D, Simonton S, Mehta P. Caregiver stress and burnout in an oncology unit. Palliat Support Care 2006;4(1):65-81.

13. Sipos D, Varga V, Pandur AA, Kedves A, Petőné CSM, Cseh $S Z$, et al. Burnout level among radiology department workers in Hungary. Orv Hetil. 2019;160(27):1047-1056.

14. Maslach C, Jackson SE, Leiter M, et al. Maslach Burnout Inventory Manual. Consulting Psychologist Press, Palo Alto, CA, 1996.

15. Bencés I. Nurses and burnout. Nővér. 2006;19(3):10-16.

16. Kovacs Á, Hadjiev J, Lakosi F, Vallyon M, Cselik Zs, Bogner $P$, et al. Thermoplastic patient fixation: Influence on chest wall and target motion during radiotherapy of lung cancer. Strahlenther Onkol, 2007;183:271-278.

17. Kovács Á, Hadjiev J, Lakosi F, Antal G, Horváth Á, Bogner P, et al. Tumor movements detected by multi-slice CT-based image fusion in the radiotherapy of lung cancer patients. HUNGARIAN ONCOLOGY, 2007;51(3):219-223.

18. Kubota $Y$, Okuyama T, Uchida M, Umezawa S, Nakaguchi T, Sugano K, et al. Effectiveness of a psycho-oncology training program for oncology nurses: a randomized controlled trial. Psychooncology, 2006;25(6):712-718.

19. Arnal VD, Romero GE, Martínez P, Corsini ML, Martínez RM, Morales P. Patient safety recommendations for out of operating room procedure sedation. Rev Esp Anestesiol Reanim. 2016;63(10):577-587.

20. Pavlish C, Brown-Saltzman K, Fine A, Jakel P. A Culture of Avoidance: Voices From Inside Ethically Difficult Clinical Situations. Clin J Oncol Nurs. 2015;19(2):159-165.

21. Révay E, Kegye A, Zana Á, Hegedűs K. The everyday life of survivors. The quality of life of hospice workers. Orv. Hetil. 2016;157(25):1000-1006.

22. Sale J, Smoke M. Measuring Quality of Work-Life: A Participatory Approach in a Canadian Cancer Center, J Cancer Educ. 2007;22(1):62-66. 
23. Daugherty J M. Burnout: How Sonographers and Vascular Technologists React to Chronic Stress. JDMS. 2002;18(5):305-312.

24. Jasperse M, Herst P, Dungey G. Evaluating stress, burnout and job satisfaction in New Zealand radiation oncology departments. Eur J Cancer Care. 2014;23(1):82-88.

25. Hegedus K. Health protection of health care personnel working with seriously ill patients. Mentálhigiéné és Pszichoszomatika 2012;13(2):243-252

26. Hegedus K, Riskó Á, Mészáros E. A súlyos betegekkel foglalkozó egészségügyi dolgozók testi és lelkiállapota. Lege Artis Medicinae. 2011;14(11):786-793.

27. Fusz K, Pakai A, Kívés Zs, Szunomár Sz, Regős A, Oláh A. Work schedules in the Hungarian health care system and the sleep quality of nurses. Orv Hetil. 2016;157(10):379_ 384.
28. Schneiderman N, Ironson G, Siegel SD. STRESS AND HEALTH: Psychological, Behavioral, and Biological Determinants. Annu Rev Clin Psychol. 2005;1:607-628.

29. Johnson J, Arezina J, McGuinness A, Culpan AM, Hall L. Breaking bad and difficult news in obstetric ultrasound and sonographer burnout: Is training helpful? Ultrasound. 2019;27(1):55-63.

30. Szényei G, Ádám S, Győrffy Z, Túry F. Prevention of burnout syndrome- from the traditions to the modern information technologies. Magyar Pszichológiai Szemle MPSzle, 2015;70(4):847-862.

31. Kovács $\mathrm{M}$, Kovács $\mathrm{E}$, Hegedus K. The relationship between emotion work and burnout. A comparative study in various groups of health care workers. Mentálhigiéné es Pszichoszomatika 2012;13(2):219-241.

32. Czeglédi E, Tandari-Kovács $M$. Characteristics and prevention of burnout syndrome among nurses. Orv Hetil. 2019;160(1):12-19. 